It is therefore suggested that these tests are no: acceptable as indicators of abnormal metabolism of L-phenylalanine and L-tyrosine. -We are, etc.,

$$
\begin{aligned}
& \text { FLEMING CARSW } \\
& \text { Royal Hospital for Sick Children, } \\
& \text { Glasgow C.4. } \\
& \begin{array}{l}
\text { King's College Hospital, W. DYMOCK. } \\
\text { London S.E.1. }
\end{array}
\end{aligned}
$$$$
\text { Fleming Carswiel. }
$$

\section{Prevention of Prolonged Labour}

SIR,-I read with great interest and enjoyment the article under the above title by $\mathrm{Mr}$. $\mathbf{K}$. O'Driscoll and his colleagues in your issue of 24 May (p. 477).

Those of us familiar with the National Maternity Hospital will be aware that the practice of this institution reflects modern obstetrics at its best, and the authors are to be congratulated upon their results.

For some years I have been a firm advocate of stimulation of labour both in private and hospital practice, and when proper supervision is exercised can confirm absolutely the desirability of this mode of management. However, may I beg to add a warning note from points made in the opening preamble under the heading, "Three Popular Fallacies" ? In my opinion prolonged labour, if allowed to occur, is still on occasion a reflection of at least relative cephalo-pelvic disproportion, and if in the course of a stimulated labour cervical stasis persists for four hours at most the case must be very carefully reviewed with a strong bias towards abdominal delivery. I have found that this policy has revealed a number of unexpectedly large babies whose future might well have been compromised by a difficult vaginal delivery had this been permitted to take place.I am, etc.,

Nassau, Bahamas.

C. J. B. ORr.

\section{Abortion Act in Practice}

SIR,-Dr. R. W. Penny (26 April, p. 248) and Drs. D. C. Sturdy and R. J. D. Browne (17 May, p. 447) raised the question of the ethical dilemma a second doctor may encounter when consulted by a woman whose regular general practitioner has refused to recommend her request for abortion.

Few if any doctors would claim that in considering a request for therapeutic abortion they are able completely to divorce themselves from their religious, moral, and ethical beliefs and attain an objective and detached viewpoint. Inevitably the woman refused abortion by her general practitioner is likely to believe, even if mistakenly, that the refusal was based on such grounds. She is quite likely to feel a sense of aggrievement and resentment, and when, as is her undoubted right, she seeks a second opinion, she may state that she is unwilling to allow the second doctor to contact the first.

When a doctor is consulted in such a way he has three possible courses of action. Firstly, he may refuse to consider the case unless and until he has permission from the original general practitioner ; an action which may be harsh and neglectful in the face of obvious and genuine distress. Secondly, he may insist on the patient writing and signing a declaration to him and to her original general practitioner that she wishes to change practices forthwith, thus withdrawing from the list of her original general practitioner. Or, thirdly, he may agree to consider the problem but insist upon notifying the general practitioner of any decision he reaches. It is this last course of action which has offended Drs. Penny, Sturdy, and Browne, but the motive may well have included a desire not to deprive a colleague of a patient.

The whole dilemma can be avoided if all doctors who refused to recommend an abortion would make it perfectly clear to their patient that she is at liberty to seek a second opinion with his full approval.-I am, etc.,

Nottingham.

G. J. Davies.

\section{Treatment of the Phobic Anxiety State}

SIR,-I hope I can reassure Dr. G. C. Wilson (14 June, p. 694) about the safety of combining the monoamine-oxidase inhibitor antidepressant drugs, in suitable dosage and given only during the day, with the tricyclics, especially tryptizol and trimipramine, 50-150 mg., best given in the evenings. By separating the giving of the two drugs in this way one can also better cope with any side-effects. For instance, if the patient is sleeping too deeply on the tricyclic drug the dose can be reduced; likewise if the patient is showing postural hypotensive symptoms on the monoamine-oxidase inhibitor drug during the day the dose is also lowered; but one need not stop using either drug. We have used combined antidepressant drugs now on literally thousands of in- and outpatients, and have repeatedly written about it over the past few years. $^{1}$ Dr. D. R. Gander, from this department, has also published a special symptomatic study of patients treated with combined antidepressants. $^{2}$ There were very few sideeffects, and none of them dangerous.

In their article (1 March, p. 559) on the treatment of phobic anxiety states, I am fully aware that Professor Martin Roth and Dr.

D. H. Myers said that it was dangerous to combine both groups of drugs in this way. This is partly why I wrote this letter. A warning is also still given in the drug pamphlets sent out with these drugs, and a warning to this effect was also issued by the Dunlop Committee. However, I feel that people have mostly repeated each other's fears and warnings without checking the actual facts at the bedside.

A possible explanation of some of the present quite unmerited fear of combining the antidepressant drugs may lie in the following facts. Only two or three deaths from supposedly combining antidepressant drugs in proper dosage have ever been actually reported in the literature. These were some time ago, and before the fatal results possible from the taking of cheese with the monoamine-oxidase inhibitor drugs were known about. Some months ago a patient of mine, who had had combined antidepressant drugs for over three months, died suddenly while taking Parstelin (tranylcypromine and trifluoperazine) during the day and trimipramine at night. Of course this was immediately blamed by others on the use of combined drugs and a coroner's inquest ordered. This gave me time to set about looking for the real cause of death. This I was able to find out on careful inquiry. A large meal of macaroni cheese had in fact been eaten by him an hour before his fatal symptoms started.

This finding had not been known to my registrar treating the patient, who reached me by phone only after his death. I then also asked the pathologist to examine the stomach contents, especially for cheese. This, too, was found in large amounts. The coroner's verdict was death due to a cheese reaction. If I had not bothered to make these inquiries it would almost certainly have been wrongly attributed to combining the antidepressant drugs.-I am, etc.,

$$
\begin{aligned}
& \text { WILLIAM SARGANT. } \\
& \text { Department of Psychological } \\
& \text { St. Medicine } \\
& \text { Tonomas's Hospital, } \\
& \text { London S.E.1. } \\
& \text { REFERENCES } \\
& \text { I Sargant, W. W., Lancet, 1963, 2, } 634 . \\
& \text { 2 Gander, D. R., Lancet, 1965, 2, 107. }
\end{aligned}
$$

\section{Potassium Supplementation}

SIR,-I am rather puzzled by the reference to "resin-based tablets" in the paragraph discussing potassium supplementation in the "Today's Drugs" article on hypotensive drugs (17 May, p. 430).

The statement is made that "resin-based tablets may pass through the gut unchanged." As a very large proportion of potassium chloride tablets being used at present are the wax-based Ciba tablets known as Slow-K, and few, if any, resin-based tablets are in use, many readers might wrongly assume that Slow-K is in fact resin-based and, as such, liable to the problem referred to. Certaisly there is no evidence of Slow- $K$ tablets passing through the gut unchanged, although "ghost" cores consisting of the wax matrix have occasionally been reported in the faeces. It has, however, been clearly shown that the potassium in Slow-K is completely absorbed. ${ }^{1}$ Analysis of "ghost" tablets has also shown that they have yielded up their potassium content in passing through the gut.-I am, etc.,

\section{Ciba Laboratories Ltd., \\ Horsham, Sussex. \\ REFERENCE \\ 1 Wynn, V., Lancet, 1965, 2, 1241.}

J. E. YARBorough.

${ }^{*} *$ We regret that the use of the term " resin-based" was inaccurate.-ED., B.M.f.

\section{Points from Letters}

\section{Tetracosactrin}

Dr. A. F. TAylor (Director, Medical Development, Organon Laboratories Ltd., Surrey) writes: May I draw attention to an omission from your useful article "Corticotrophin and its Synthetic Analogues" (28 June, p. 809). Tetracosactrin is available in the United Kingdom as Cortrosyn and as a long-acting zinc hydroxide complex, Cortrosyn Depot. Cortrosyn is available in sterile ampoules each containing 0.25 mg. freeze-dried tetracosactrin. Cortrosyn Depot is presented in $2 \mathrm{ml}$. vials containing concentrations of $0.5 \mathrm{mg} . / \mathrm{ml}$. or $1 \mathrm{mg} . / \mathrm{ml}$. 